\title{
Unconventional gas resources in the Cantabrian Zone (NW Spain): A comprehensive preliminary assessment
}

\author{
R. Alvarez ${ }^{1}$, A. Ordóñez ${ }^{1}$, P. Canteli², E. De Miguel ${ }^{3}$
}

${ }^{1}$ Dep. Explotación y Prospección de Minas. University of Oviedo. Escuela de Ingeniería de Minas, Energía y Materiales, c/Independencia, 13, 33004, Oviedo, Asturias, Spain. aoalonso@uniovi.es

${ }^{2}$ Dep. Investigación en Recursos Geológicos, Geological Survey of Spain, Madrid (IGME)

${ }^{3}$ Environmental Geochemistry Research and Engineering Laboratory. Universidad Politécnica de Madrid, Spain

\begin{abstract}
With the aim of acquiring a better knowledge of the potential for unconventional gas resources in Spain, 134 rock samples were taken from 12 lithostratigraphic units in the Cantabrian Zone (Northwest Spain) and studied for a three-year period. The selected units gather, a priori, the basic conditions to constitute potential source rocks for unconventional hydrocarbons. Petrographic studies and Total Organic Carbon analyses were carried out for all samples, whereas Rock-Eval pyrolysis and vitrinite reflectance measurements with kerogen visual analysis were performed on selected samples. Lutites, litharenites, limestones and slates are the predominant petrographic types. In most cases, the mean Total Organic Carbon content is below the $2 \%$ limit for good quality potential source rocks. Only the Jurassic Rodiles and Tereñes limestones show Total Organic Carbon values above this threshold. Rock-Eval data reveal very low potential for hydrocarbon generation in almost all cases, with the exception of the dark mudstones of the Carboniferous Barcaliente Formation and the Rodiles Formation (fair and good potential for hydrocarbon generation, respectively). As regards thermal maturation, only the Ordovician formations are located in the peak of the gas generation interval. The Barcaliente and the Rodiles formations are near the frontier oil/wet gas maturation areas, and the rest of the units are immature for gas generation.
\end{abstract}

Keywords Cantabrian Zone, organic carbon content, Rock-Eval test, source rock, unconventional gas resources, vitrinite reflectance

Correspondence: A. Ordóñez, Dep. Explotación y Prospección de Minas. University of Oviedo. Escuela de Ingeniería de Minas, Energía y Materiales, c/Independencia, 13, 33004, Oviedo, Asturias, Spain. Email: aoalonso@uniovi.es 


\section{INTRODUCTION}

During the last two decades, the importance and interest of the so-called "unconventional hydrocarbon resources" has grown progressively (Jiang et al., 2017). There are many types of unconventional gas resources, whose characteristics are widely described and can be easily found in the specialized literature (e.g. Jarvie, Hill, Ruble, \& Pollastro, 2007; McGlade, Spiers, \& Sorrel, 2013, Ross \& Bustin, 2008): tight gas, gas shale, deep gas, coal bed methane (CBM), coal mine methane (CCM) and gas hydrates. From a technical and economic point of view, "gas shale" type resources have recently had a large-scale development, achieving notorious productions by combining horizontal drilling and hydraulic fracturing, mainly in the US and Canada. The main causes for the validation of these resources are: i) they can be found worldwide (exploration is currently under way in America, Asia, Europe, Africa and Australia), ii) there are high reserve estimations in many countries (with long production life) and iii) they constitute the last significant on-shore option for hydrocarbon extraction. A preliminary assessment made by the US EIA (2015) estimates the technically recoverable world shale gas resources at $7299 \mathrm{Tcf}$. The top-ten countries with technically recoverable gas resources from gas-shale systems are (in order of importance): China, Argentina, Algeria, US, Canada, Mexico, Australia, South Africa, Russia and Brazil.

The main properties of gas-shale resource systems are also well known: sedimentary fine-grained and organic-rich rocks that can be simultaneously regarded as source and seal rock with a good spatial continuity (mappable) and homogeneity at a basin scale (Gao et al., 2016). They are usually shale rocks of marine depositional environment with thermal maturity within the gas window $\left(>1.25 \%\right.$ of vitrinite reflectance $\left(\mathrm{R}_{0}\right)$ for kerogen type $\mathrm{II} ;>1.35 \%$ in the less common case of kerogen type I or type III).

Although both governments and several private companies have made an effort in the characterization of potential gas-shale type resources in recent years, their assessment in Europe is still at a very early stage. Regarding Spain, the only published data concerning gas-shale resources is a gross estimation that only takes into account the Camino and Pedroso formations (lower Jurassic) in the Basque-Cantabrian Basin. Estimated recoverable gas reserves for both levels, establishing a total organic carbon content (TOC) cut-off of $2 \%$, are about 8 Tcf in a prospective area of $5400 \mathrm{~km}^{2}$. Gessal (2013) estimates a total of $70 \mathrm{Tcf}$ for the whole on-shore Spanish unconventional gas resources.

The Cantabrian Basin is located west of the Basque-Cantabrian Basin. It constitutes, from a geological point of view, the foreland of the NW Iberia Hercynian chain (Alonso, Marcos \& Suárez, 2009; Lotze, 1945). It is constituted mainly by Palaeozoic sequences, with a great development of Devonian and, especially, Carboniferous rocks. Its north-central part, an area of more than $1200 \mathrm{~km}^{2}$, is covered by Mesozoic series, setting up a large outcrop very similar to that of the Basque-Cantabrian Basin. During the 1970s and 1980s, some seismic surveys and deep drills (1000-5000 m) were promoted in this area by private companies (Shell, Campsa and Phillips Petroleum Co.) to evaluate the existence of conventional oil resources, mainly off-shore. The aim of these prospecting campaigns were possible conventional oil reservoir systems, considering Liassic limestones, Lower Cretaceous sandstones, and Upper Cretaceous argillites as source, reservoir, and seal rocks, respectively. Some published results about these investigations (Gutiérrez-Claverol \& Gallastegui, 2002) pointed out that evidences of oil and/or gas were found in the majority of the drills; notwithstanding, there has never been a commercial production. On the other hand, the Central Coal Basin $\left(1400 \mathrm{~km}^{2}\right)$ is the largest Carboniferous outcrop in Spain, and about $70 \%$ of the historical Spanish coal production (currently in clear decline) came from this area. During the last decade, some studies to evaluate the coal bed methane potential of this zone have been carried out (Cienfuegos \& Loredo, 2010; Fernández, 2006; Sastre, 2013). No methane has been economically recovered as of yet, although Cienfuegos \& Loredo (2010) have estimated a minimum of $25,100 \mathrm{Mm}^{3}$ of gas (methane) resources in this basin. 
Having a better knowledge of a country's natural resources is of great importance for its economy, and it can be critical for economic development. This fact, together with the lack of published data suitable to estimate the potential existence of shale-gas resources in the Cantabrian Basin (filled with Palaeozoic and Meso-Tertiary materials), has led us to sample and study some lithostratigraphic units within this area. Selected sedimentary horizons fulfil the necessary conditions to constitute an adequate source rock for shale-gas resources (fine-grained and dark tone units, mappable at a basin scale). There is some previous published data about direct and indirect indicators of the thermal evolution (i.e., organic matter maturation) of some of the sampled areas, but there are no previous studies on organic matter quantity and quality, both necessary for an admissible gas resources assessment. The main results are presented and discussed throughout this paper.

\section{STUDY AREA}

The Cantabrian Zone (CZ) is one of the areas in which the Hesperian (or Iberian) massif has been classically divided (Lotze, 1945) and it corresponds geographically with the Central and Eastern part of Asturias (NW Spain, Figure 1). The CZ is very complex from a structural point of view, given the presence of pre-orogenic (Variscan), syn-orogenic and post-orogenic sets of sedimentary rocks. Six different sub-units are defined within the CZ, based on both stratigraphic and structural features. From west to east, these sub-units are: Somiedo, La Sobia-Bodón, Aramo, Central Coal Basin, Ponga and Picos de Europa (Figure 1). In the northern part of the CZ, the Palaeozoic basement is covered through an angular discordance by a thick succession of sedimentary rocks of Permian, Mesozoic and Tertiary ages, generally known as "Meso-Tertiary cover". The north coastal stripe of the Meso-Tertiary cover is mainly constituted of Jurassic limestones, marls and sandstones, whilst the southern stripe, which follows an E-W direction, forms a lax anticline with Tertiary rocks at the core, and Cretaceous levels in the flanks. Some previous results about the thermal maturity of each sub-unit are described, summarized and discussed below.

Somiedo and La Sobia-Bodón-Aramo units: following the Conodont Alteration Index (CAI) and Kubler Index (KI) results of previous works (see Table 1), most of these areas are in the diagenetic domain, with different maturity degree, that is usually slightly lower in the syncline cores and higher in the folds flanks. Anchizone conditions (measured by CAI, García-López et al., 2007) have been locally detected in the western boundary, particularly in a narrow strip (1-2 km thick) parallel to the thrust that constitutes the limit between the CZ and the West-Asturian Leonese Zone (WALZ). Another remarkable feature is the existence of small outcrops of igneous bodies in the Somiedo sub-unit that generate metamorphism aureoles of 2-3 $\mathrm{km}$ of influence, even reaching epizone (epicaizone) conditions.

Central Coal Basin: this is the sub-unit with more available data about thermal maturity, mostly obtained by vitrinite reflectance of Westphalian coals, as well as fluid inclusion geothermometry in samples from fluorite mineral deposits. Fluid inclusion data should be considered in a restricted local context, as they were measured in samples from hydrothermal mineralizations that appear disperse within the Carboniferous sequence, mainly in the extension to the north of this unit (Sueve Massif area). The spatial distribution of the maturity degree in the sediments filling the coal basin does not seem to be only due to burial. As it were, vitrinite isoreflectance maps (Colmenero, Suárez-Ruiz, Fernández-Suárez, Barba, \& Llorens, 2008) show a decreasing gradient from south $\left(2.5 \% \mathrm{R}_{0}\right)$ to north $\left(1.1 \% \mathrm{R}_{0}\right)$. Although it has never been directly observed, Piedad-Sánchez et al. (2004a) have suggested the presence of not outcropping, deep, intrusive rocks in the south border of the basin, in the vicinity of the León Fault.

Ponga unit: suitable data about the thermal evolution of this sub-unit are less abundant. However, some measurements of fluid inclusions (see the above consideration about their validity), vitrinite reflectance, and CAI can be found in previous works. The CAI data (more reliable and better geographically distributed) indicate a great homogeneity of maturity in the north part of this subunit, within the diagenetic domain. The anchizone (anchicaizone) is not reached even in the more mature areas, where hydrothermal ore deposits exist. More detailed information about this sub-unit 
is presented and discussed in Blanco-Ferrera, Sanz-López, García-López, Bastida and Valín (2011).

Picos de Europa unit: just as in the previous unit, the availability of thermal evolution data is limited. Homogenization temperatures of fluid inclusions in mineral ore deposits are scarce and they are located in a similar interval to those found in the Central Coal Basin and the Ponga unit (between $100^{\circ}$ and $150{ }^{\circ} \mathrm{C}$ ). CAI values obtained along the Cares River section reveal a diagenetic zone-anchizone (diacaizone-anchicaizone) net separation in relation with the autochthonous and allochthonous blocks of the main E-W trend thrust structure. As a result, the southern area is more mature than the northern one. Further information about the thermal evolution of this unit can be found in García-López, Blanco-Ferrera and Sanz-López (2006).

Meso-Tertiary cover (including Permian sediments): published data concerning the thermal state of this series are related to organic-rich Liassic rocks and thin layers of jet of Kimmeridgian age. Their spatial distribution is restricted to the coastal sector between $5^{\circ} 39^{\prime}$ and $5^{\circ} 45^{\prime}$ west longitude and, generally, they are immature rocks for gas generation.

The most important studies with direct or indirect information regarding the thermal evolution of the basement and cover of the $\mathrm{CZ}$ are compiled in Table 1.

\section{METHODS}

For the purpose of this study, 12 lithostratigraphic units were selected for sampling and analysing (Figure 2). As it is shown in Table 2, selected units include mainly sedimentary rocks (lutites, sandstones, greywackes and limestones) and slightly metamorphic rocks (slates) in one case. Concerning their age, the oldest units are Ordovician (Dobrotivian, $458 \mathrm{Ma}$ ) and the youngest one is Jurassic (Kimmeridgian, $152 \mathrm{Ma}$ ); the Upper Carboniferous (299-323 Ma) is a period of special interest, as half of the studied rocks were formed during this short interval. Samples were directly taken from outcrops in all cases, avoiding the most surficial parts (Figure 3). The use and suitability of outcrop samples in organic geochemistry tests, particularly in the Rock-Eval pyrolysis, has been a matter of concern in previous studies. Although there is not a general agreement, most recent studies (Emmings et al., 2018 and references therein) have pointed out that outcrop samples can underestimate the hydrocarbon generation potential but without significant differences in the magnitude of the Rock-Eval parameters, when compared with core samples. After being air dried, thin and polished sections were prepared, when possible, for conventional petrographic studies; reflected light observations were carried out to identify opaque minerals. Classical mineralogical studies such as optical polarizing microscope and X-ray diffraction (XRD) were undertaken. Additionally, the organic geochemistry of collected samples was determined by combining three types of determinations: Total Organic Carbon (TOC), Rock-Eval pyrolysis, and vitrinite reflectance. In some cases, a visual analysis of the kerogen was also carried out.

In order to determine the mineralogy and texture of the samples, petrographic studies were performed over thin and polished sections by means of a Leica DMLP polarizing microscope at the Ore Deposits Laboratory of the School of Mines (University of Oviedo). XRD analyses were performed at the Scientific Equipment Unit of the University of Oviedo using the crystalline powder method, by means of a Bruker D8 Discover diffractometer ( $\mathrm{Cu} K \alpha$ radiation). Operating conditions concerning voltage and anodic current were $45 \mathrm{kV}$ and $40 \mathrm{~mA}$, respectively. TOC determinations and Rock-Eval pyrolysis were carried out in the Source Rock Geochemistry Unit of Weatherford Labs (Houston, Texas, USA) with a Rock-Eval VI instrument. TOC values indicate the quantity of organic matter present in the sample and, consequently, are closely related to its hydrocarbon generation potential (good source rocks usually present high TOC values). See Behar, Beaumont, \& Penteado, 2001; Lafargué, Espitalié, Marquis, \& Pillot, 1998 and references thereinFor equipment description. 
Rock-Eval pyrolysis is a routine analysis of source rock based on the controlled heating of samples in an inert atmosphere at a constant heating rate, monitoring the evolution of organic compounds. It is widely used to estimate the potential of a rock to generate hydrocarbons. The main parameters (S1, S2 and S3 peaks, $\mathrm{T}_{\max }$ and Hydrogen -HI- and Oxygen -OI- Indexes) can be used to elucidate the hydrocarbon generative potential of the tested sample. Detailed information about the procedure and the obtained parameters are described in Dembicki (2016), Lafargue et al. (1998), Peters (1986) and Peters, Walters \& Moldovan (2005).

Vitrinite reflectance and kerogen visual analysis were also determined on a polished section of the samples at Weatherford Labs following the standard ISO 7404-5:2009. Vitrinite reflectance, as it was previously indicated, constitutes a robust thermal maturity indicator and the kerogen visual analysis provides interesting details about the organic matter nature (type of kerogen).

\section{RESULTS AND INTERPRETATION}

Results are described in the following paragraphs from western to eastern units, and from older to younger sedimentary rocks. Main petrographic types are listed in Table 2.

\subsection{Mineralogy and texture}

Luarca Formation: low and very low-grade metamorphic rocks with a foliated texture with a mineralogy constituted by phyllosilicates $(55-92 \%)$ quartz $(1.5-30 \%)$, rock fragments (3-4\%), muscovite (1-9\%) and opaque minerals (1-3\%). Common small grain-sized phyllosilicates have been identified as clinochlore by means of XRD.

Formigoso Formation: siliciclastic unit containing quartz (11-88.5\%), argillaceous detrital matrix (9-73.5\%), muscovite (0.5-4\%) and opaque phases (up to 13\%) as main components. Rock fragments, zircon, calcite and dolomite (the latter as late cement) can be occasionally found. Most common texture type is silty-clayey.

Rañeces Group: carbonates in which the common Dunham types are wacke- and packstone with bioclasts (bivalve fragments, bryozoan, echinoderms...) as skeletal grains. Mineralogy is dominated by calcite (about $80 \%$ ), ankerite (10\%) and, to a lesser extent, quartz, kaolinite, and muscovite.

Naranco Group (Folgueras and Carriles formations): the Folgueras and the Carriles mining packages are quite similar and both constitute the Upper Carboniferous Series of the Naranco Syncline (north of the city of Oviedo, Figure 1). They have been traditionally differentiated because the oldest one (Folgueras Fm.) contains thin limestone horizons that are not present in the youngest one (Carriles Fm.) and, on the contrary, a few minable coal seams have been exploited in the Carriles mining package, whereas none is known in the Folgueras mining package. From a mineralogical point of view, the predominant constituents are quartz (10-82\%), matrix (mainly kaolinite, 3-81.5\%) and rock fragments (3-20\%) . Common minor components are muscovite (up to $2.5 \%$ ) and opaque grains (2-4\%). Grain size is predominantly in the very fine sand interval.

San Emiliano Formation: matrix (kaolinite and clinochlore, determined by XRD, 6-80\%) and quartz (12-40\%) predominate over other minor components such as opaque minerals (2-4\%), muscovite (1-5\%) and rock fragments (up to $0.5 \%$ ). This thick lithostratigraphic unit is very fine grained, showing a clayey texture.

Sueve Formation: dark-coloured fissile rocks with quartz (4-93\%), clinochlore and muscovite (4$85 \%)$ as main components and minor quantities of opaque minerals (4-7\%), illite and montmorillonite (up to $3 \%$ ). The oldest record of petroleum evidence within the Iberian Peninsula (as regards the reservoir rock) has been found in this unit during the drilling of the Fabar tunnel (60 km north-east of Oviedo, Gutiérrez-Marco \& Bernárdez, 2003).

Fresnedo Formation: thick sequence constituted by centimetric detrital levels distributed in several transgressive-regressive cycles. Main mineralogy is quartz (35-68.5\%), rock fragments (2-5\%), 
muscovite (up to 9\%) and opaque constituents (up to 8\%). With a minor quantitative importance, the following constituents can be occasionally found: argillaceous matrix (clinochlore), albite and calcareous cement (dolomite).

Barcaliente Formation: thick and extremely homogeneous level of laminated, micritic and fetid carbonates of mudstone type. The mineralogical composition is constituted almost exclusively by calcite (micrite and microsparite crystals) with minor opaque phases (up to 1.5\%).

Beleño Formation: siliciclastic deposits in which quartz (5-79\%), matrix (4-82\%) and muscovite $(1.5-7 \%)$ are, once again, the predominant constituents. Other phyllosilicates and opaque minerals are also present, although in moderate proportions.

Fito Formation: the granular fraction of dominant clastic nature contains muscovite $(0.5-1 \%)$, together with quartz (60-79\%) and metamorphic rock fragments (12-30\%). This unit exhibits some marl levels (particularly in the lower part) and coal seams.

Rodiles Formation: rhythmic sequence of marl/shale (laminated, black) limestone (bioclastic) intervals. Calcite (micrite) is the most common constituent of limestones, usually accompanied by quartz (0.5-1.5\%) and illite (up to 0.5\%) in the marly lithologies. Suárez-Ruiz \& González-Prado (1995) mentioned the potential economic interest of the black shale horizons as hydrocarbon source rocks.

Tereñes Formation: mud- and wackestone biomicritic carbonates and marls with minor detrital horizons interbedded. Shelly (mainly bivalves) layers are common. Silt-size detrital quartz (1-18\%) and muscovite (up to $1 \%$ ) are quite common in marly levels.

Figure 3 shows outcrop and thin section images of some of the sampled rocks.

\subsection{TOC}

A summary of the results of the organic geochemistry of the collected samples is presented in Table 3. Although there are some quantitative scales to estimate hydrocarbon potential from TOC content (Holdtich, 2011; Jarvie, 1991; Peters et al., 2005; among others), many authors have drawn attention to the oversimplification of using TOC alone for this purpose (this topic is extensively discussed in Dembicki, 2009).

Based on thermal maturation in the early oil window, Holdtitch (2011) proposed a potential estimation of hydrocarbon generation from TOC values, differentiating between fine-grained clastic source rocks and carbonate source rocks. Using this proposal (Table 4) as a reference, most of the detrital rocks studied here should be relegated to a second-order interest, since their low TOC values make them unattractive as potential source rocks. Only the cases of the San Emiliano and Fito formations (1.01\% and $1.07 \%$ TOC, respectively) would be suitable for further studies, given that their hydrocarbon generation potential lies in the fair-good region. Regarding limestone units, the Palaeozoic thick sets (Rañeces Group and Barcaliente Formation) exhibit a fair potential for hydrocarbon generation, whereas the Jurassic rocks provide, by far, the highest TOC values ( $2.67 \%$ for Rodiles Formation and $1.33 \%$ for Tereñes Formation); the hydrocarbon generation potential is thus excellent in the Rodiles Formation and very good in the Tereñes Formation. It is important to note that, as it was stated before, all samples were taken in outcrops (see comments in the Methods section).

Although rocks with very low TOC values can be directly discarded as source rocks, rocks with high TOC values are not necessarily good source rocks, since carbon needs to be closely linked to hydrogen in order to generate hydrocarbons from organic matter. Therefore, the TOC value should be complemented with an estimation of the hydrogen associated to carbon for a correct and complete interpretation of the actual hydrocarbon generation potential of the rock. The most 
common (indirect) determination of the hydrogen present in a potential source rock sample is done by means of the $\mathrm{S} 2$ peak of the Rock-Eval test.

\subsection{Rock-Eval Pyrolysis}

Comparing the S1, S2 and S3 data of the collected samples with reference values (hydrocarbon potential as a function of peaks S1 and S2 values, Table 5) a very low response for pyrolysis in nearly all the samples is deduced. The temperature $\left(\mathrm{T}_{\max }\right)$ achieved at the moment when peak $\mathrm{S} 2$ maximizes (best rate of hydrocarbon generation) can be correlated with vitrinite reflectance (see next section), thus allowing a thermal maturity approximation. $\mathrm{T}_{\max }$ data has not been included in Table 3, as many authors (Peters et al., 2005 and references therein) have stated that a poor response to pyrolysis ( $\mathrm{S} 2$ value under $0.5 \mathrm{mg} / \mathrm{g}$ ) invalidates $\mathrm{T}_{\max }$ values. Therefore, only data of $\mathrm{T}_{\max }$ of Jurassic rocks and the Folgueras+Carriles and Barcaliente formations would be accepted and, even in these cases, vitrinite reflectance offers a more reliable assessment.

S1 should be interpreted as the quantity of hydrocarbons that can be thermally distilled from the sample. All the sampled potential source rocks have a poor potential, except the Sinemurian Rodiles Formation (S1=1.36 mg hydrocarbon/g rock, good potential) and the Barcaliente Formation ( $\mathrm{S} 1=0.76$, fair potential). A similar conclusion can be derived from $\mathrm{S} 2$ values (hydrocarbons generated by kerogen pyrolytic degradation): all samples provide very low values (below $2.5 \mathrm{mg}$ hydrocarbon/g rock, poor hydrocarbon generative potential) with the exception of the Rodiles Formation (fair potential).

$\mathrm{HI}$ (mg hydrocarbon/g TOC) and $\mathrm{OI}\left(\mathrm{mg} \mathrm{CO}_{2} / \mathrm{g}\right.$ TOC) indexes are equivalent to $\mathrm{H} / \mathrm{C}$ and $\mathrm{O} / \mathrm{C}$ ratios in kerogen elemental analysis. A source rock quality estimation from Rock-Eval results can be performed by plotting HI vs OI values on a diagram in which type I, type II and type III kerogen trends are indicated (pseudo-van Krevelen diagram, Figure 4). Most of the points plotted on the pseudo-Van Krevelen diagram are located below the trend of the type IV kerogen (inert carbon). The organic matter from the Barcaliente Formation seems to be constituted of a mixture of type II and type III kerogens, and the organic fraction from the Rodiles Formation falls on the type III kerogen. This is debatable, in so far as the depositional environment for both units (Aurell et al., 2002; Hemleben \& Reuther, 1980) is clearly marine. In this sense, Suárez-Ruiz \& González-Prado (1990) have determined a type II kerogen for the Rodiles Formation based on kerogen isolation and visual analysis (a much more adequate procedure than Rock-Eval data for an accurate determination of the kerogen type). As it is widely discussed in the specialized bibliography (Dembicki, 2009; Jarvie, 2012; among others) HI derived from a Rock-Eval pyrolysis can underestimate kerogen quality. Firstly, HI and OI vary with thermal maturation and, consequently, organic facies cannot be deduced only by these index values; on the other hand, some authors (Espitalié, Madec, \& Tissot, 1980; Katz, 1983) have pointed out that in potential source rocks with TOC content below $1 \%$, the hydrocarbons generated are easily retained on the surface of mineral grains (depending, therefore, on the mineral matrix of the potential source rock), and the HI value can be significantly reduced. Since the great majority of the studied samples provide TOC mean values less than $2 \%$, it is not wise to make reliable conclusions on this aspect. The very high OI values obtained in samples from the Rañeces Group and the Naranco Group (Folgueras+Carriles formations) may indicate an advanced state of weathering. Lack of kerogen oxidation can be assumed for the rest.

It should be noted that the Rock-Eval test has been carried out over one sample of each section (the one with a higher proportion of opaque minerals, after being studied by optical polarizing microscopy). Thus, the TOC value of each one of these samples does not necessarily match the mean value (or the maximum) shown in columns 3 and 4 of Table 3, so the theoretical equations $\mathrm{HI}=(\mathrm{S} 2 \cdot 100) / \mathrm{TOC}$ and $\mathrm{OI}=(\mathrm{S} 3 \cdot 100) / \mathrm{TOC}$ are not applicable to data on this Table. 


\subsection{Thermal maturity (Vitrinite reflectance and TAI)}

Since vitrinite reflectance varies with temperature in a predictable way, this parameter $\left(\mathrm{R}_{0}\right)$ has classically been used as a thermal maturation indicator by establishing maximum paleotemperatures (Mukhopadhyay, 1992). Although slightly dependent on kerogen type, the conventional stages of oil generation can be defined from the vitrinite reflectance value (Table 6).

Not all organic-rich rocks contain vitrinite, as it does not exist in lower Palaeozoic rocks; moreover, higher plants fragments are very rare in certain depositional environments. Therefore, sometimes it is not possible to establish maturity from its reflectance. In these cases, reflectance measurements can be made on kerogen particles with a similar appearance to vitrinite (the socalled "vitrinite-like" particles). On the other hand, the Thermal Alteration Index (TAI) is an alternative maturation parameter based on the progressive change in colour of palynomorphs with increasing temperature (Rejebian, Harris, \& Huebner, 1987). The correlation between the TAI scale and the vitrinite reflectance scale has already been established and it is well known (for further details see Dembicki, 2016, p.114).

The vitrinite reflectance data shown in Table 3 are mean values over 20-50 measurements carried out on a polished section of the sample of each unit with highest TOC value. In samples from lower Palaeozoic formations, reflectance measurements were carried out on "vitrinite-like" particles (solid bitumen or pyrobitumen), and the results were translated into vitrinite reflectance equivalent by means of the Jacob's equation (1989).

The type of hydrocarbons that a potential source rock can generate depends, besides its thermal maturity, on the predominant kerogen type. Most of the studied rocks contain kerogen type II, and gas generation, in terms of maturity, would begin above 1.2-1.3\% $\mathrm{R}_{0}$. As shown in Table 3, only Ordovician rocks (Luarca and Sueve formations) and the Barcaliente Formation (Namurian) are within the gas generation interval in their respective sampling sections. It should be pointed out that $\mathrm{R}_{0}$ as a thermal indicator is a local measurement, valid in the sampling area and surroundings, but not at the basin scale. Silurian and Jurassic potential source rocks are located near the border between the oil and the condensate/wet gas windows (Table 6). On the contrary, and continuing with rocks with kerogen type II, the San Emiliano and Beleño formations are immature for gas generation, and lie within the oil generation zone.

In the absence of other data, it can be concluded that rocks whose dispersed organic matter contains kerogen type III (or types II/III), i.e., Naranco Group, Fresnedo and Fito formations, are not so attractive for gas generation. Furthermore, all of them are also immature for thermogenic gas generation $\left(\mathrm{R}_{0} \leq 1.35 \%\right.$ in all cases $)$.

The data of organic matter quantity, potential to generate hydrocarbons, and maturation of all the studied lithostratigraphic units are jointly presented in Figure 5, so that they can be compared. This diagram indicates that only the Rodiles Formation could be further studied in depth as to assess its potential economic interest. With due reservations, the Barcaliente formation, in spite of its fair potential to generate hydrocarbons, can be considered as a potential interesting source rock, taking into account its net thickness, regional distribution, and high HI value.

\section{CONCLUSIONS}

Selected potential source rocks are lutites and siltstones with minor greywacke terms (Formigoso, San Emiliano, Sueve, Beleño, Fito, Fresnedo formations, and Naranco Group) and the rest are dark-coloured limestones, excepting the very low-grade slates of the Luarca formation. For the first group, the rock mineralogy is mainly constituted by quartz, muscovite and argillaceous matrix, with minor quantities of rock fragments and opaque minerals. Calcite cement is very scarce. Limestones are usually of the mudstone type (micritic matrix) with a moderate representation of the wackestone variety. The predominant type of grain is bioclasts, among which bivalves are the 
predominant species in Jurassic limestones, whereas crinoids, bivalves and bryozoans are more common in Devonian rocks.

Regarding TOC results, and following the classification proposed by Holdtich (2011), the Naranco Group and the San Emiliano, Fito, Tereñes and Barcaliente formations exhibit a fairly good potential for hydrocarbon generation in accordance with their TOC values. The most attractive potential source rock regarding mean TOC values is the Rodiles formation, with very good potential. The rest of considered units show poor potential as source rocks..

Kerogen types plotted on a pseudo-Van Krevelen diagram are not in good agreement with depositional environments and/or visual kerogen analysis results. The Rodiles formation has a fair value for the HI index and the S1 and S2 peaks, being low or very low for the rest of sampled units.

Thermal maturity has been addressed through vitrinite (and pseudo-vitrinite) reflectance. Older rocks (Ordovician) are located within the wet gas generation zone. Most of the Carboniferous horizons -in all geological units- and the Silurian Formigoso formation are immature for thermogenic gas generation, falling on the oil generation zone in their respective sampling sections. The Barcaliente, Rodiles and Tereñes formations present a thermal maturity in the oil-wet gas borderline.

For further investigations and an in-depth research programme concerning unconventional gas resources in this area, Jurassic marly limestones (Rodiles Fm) should be considered a priority.

\section{ACKNOWLEDGEMENTS}

The authors thank Prof. Fernando Pendás for promoting this work and Fundación Mapfre, and the Government of the Principality of Asturias (Spain) for their support. Comments and suggestions made by Ian Somerville and another anonymous reviewer have substantially improved the original manuscript.

\section{REFERENCES}

Águeda, J.A., Bahamonde, J.R., Barba, P., Colmenero, J.R., Fernández, L.P., Salvador, C.I., \& Vera, C. (1991). Depositional environments in Westphalian coal-bearing successions of the Cantabrian mountains, northwest Spain. In: Coal: formation, occurrence and related properties, Bertrand, P. (Ed.). Bulletin de la Sociéte Geólogique de France No 162: 325-333.

Aller, J., Valín, M.L., García-López, S., Brime, C., \& Bastida, F. (2005). Superposition of tectonothermal episodes in the southern Cantabrian Zone (foreland thrust and fold belt of the Iberian Variscides, NW Spain). Bulletin de la Société Géologique de France, 176, 487-498.

Alonso, A. (1974). Aportación al estudio geológico de la mina Ambición (Caleao, Asturias). Boletín del Instituto de Estudios Asturianos (Suplemento de Ciencias) 19, 35-50.

Alonso, J.L., Marcos, A., \& Suárez, A. (2009). Paleogeographic inversion resulting from large out of sequence breaching thrusts: The León Fault (Cantabrian Zone, NW Iberia): A new picture of the external Variscan Thrust belt in the Ibero-Armorican Arc. Geologica Acta, 7, 451-473.

Alonso, O.E., \& Brime, C. (1990). Mineralogy, geochemistry and origin of the underclays of the Central Coal Basin, Asturias, Spain. Clays and clay mineralogy, 38, 265-276.

Aparicio, A., Brell, J.M., \& García, R. (1993). El metamorfismo hercínico de bajo a muy bajo grado en la Zona Cantábrica (Provincias de León, Asturias, Cantabria). Boletín geológico y minero, 104, 439-461.

Aramburu, C., \& García-Ramos, J.C. (1993). La sedimentación cambro-ordovícica en la Zona Cantábrica (NO de España). Trabajos de Geología, 19, 45-73.

Aramburu, C., Truyols, J., Arbizu, M., Méndez-Bedia, I., Zamarreño, I., García-Ramos, J.C., Suárez de Centi, C., \& Valenzuela, M. (1992). El Paleozoico Inferior de la Zona Cantábrica. In: 
Paleozoico Inferior de Ibero-América, Gutiérrez-Marco, J.C., Saavedra, J., Rábano, I. (Eds.): 397421.

Arcos, D., \& Tornos, F. (1997). Hydrocarbon fluid inclusions in quartz crystals from the fluorite stratabound deposit of Berbes (NW Spain). Abstracts of the ECROFI XIV (p. 196), Nancy, France.

Aurell, M., Menéndez, G., Olóriz, F., (Coords.), Bádenas, B., Caracuel, J.E., García-Ramos, J.C., Goy, A., Linares, A., Quesada, S., Robles, S., Rodríguez-Tovar, F.J., Rosales, I., Sandoval, J., Suárez de Centi, C., Tavera, J.M., \& Valenzuela, M. (2002). Jurassic. In: The Geology of Spain, Gibbons, W., Moreno, M.T. (Eds.).Geological Society: 213-253.

Bádenas, B., Aurell, M., García-Ramos, J.C., González, B., \& Piñuela, L. (2009). Sedimentary vs. diagenetic control on rhythmic calcareous successions (Pliensbachian of Asturias, Spain). Terra Nova, 21, 162-170.

Bahamonde, J.R., \& Colmenero, J.R. (1993). Análisis estratigráfico del Carbonífero Medio y Superior del manto del Ponga (Zona Cantábrica). Trabajos de Geología, 19, 155-193.

Bahamonde, J.R., Merino-Tomé, O., Della Porta, G., \& Villa, E. (2015). Pennsylvanian carbonate platforms adjacent to deltaic systems in an active marine foreland basin (Escalada Fm., Cantabrian Zone, NW Spain). Basin Research, 27, 208-229.

Bastida, F., Blanco-Ferrera, S., García-López, S., Sanz-López, J., \& Valín, M.L. (2004). Transition from diagenesis to metamorphism in a calcareous tectonic unit of the Iberian Variscan belt (central massif of the Picos de Europa, NW Spain). Geological Magazine, 141, 617-628.

Bastida, F., Brime, C., García-López, S., Aller, J., Valín, M.L., \& Sanz-López, J. (2002).

Tectonothermal evolution of the Cantabrian Zone (NW Spain). In: Palaeozoic conodont from northern Spain, García-López, S. Bastida, F. (Eds.): 105-123.

Behar, F., Beaumont, V., \& Penteado, H.L. De B. (2001). Rock-Eval 6 Technology: Performances and Developments. Oil and Gas Science and technology, 56(2), 111-134.

Blanco-Ferrera, S., \& Sanz-López, J., (1996).Add details

Blanco, C.G., Valenzuela, M., Suárez de Centi, C., \& Fernández-Pello Lois, M. (1996).

Características preliminares de azabaches artesanales del Kimmeridgiense de Asturias. Geogaceta, 20, 677-680.

Blanco-Ferrera, S., Sanz-López, J., García-López, S., Bastida, F., \& Valín, M.L. (2011). Conodont alteration and tectonothermal evolution of a diagenetic unit in the Iberian Variscan belt (PongaCuera unit, NW Spain). Geological Magazine, 148, 35-49.

Blanco-Ferrera, S., Sanz-López, J., García-López, S., \& Bastida, F. (2016). Tectonothermal evolution of the northeastern Cantabrian zone (Spain). International Journal of Earth Sciences, 531, 1-17.

Brime, C., \& Pérez-Estaún, A. (1980). La transición diagénesis-metamorfismo en la región del Cabo Peñas. Cuadernos del laboratorio geológico de Laxe, 1, 85-97.

Brime, C., García-López, S., Bastida, F., Valín, M.L., Sanz-López, J., \& Aller, J. (2001). Transition from diagenesis to metamorphism near the front of the variscan regional metamorphism (Cantabrian Zone, Northwestern Spain). The Journal of Geology, 109, 363-379.Bulnes, M., García-Alcalde, J.L., \& Marcos, A. (1999). Litoestratigrafía del Grupo Rañeces (Devónico Inferior) en el antiforme de Caranga-Trubia (Zona Cantábrica, NO de España). Revista de la Sociedad Geológica de España, 12, 339-349.

Cepedal, A. (2001). Geología, mineralogía, evolución y modelo genético del yacimiento de Au-Cu de "El Valle-Boinás", Belmonte, Asturias (Doctoral dissertation). Retrieved from www.tdx.cat/bitstream/handle/10803/11132/uov0034tmach.pdf? sequence=1. 
Cienfuegos, P., \& Loredo, J. (2010). Coalbed methane resources assessment in Asturias (Spain). International Journal of Coal Geology, 83, 366-376.

Colmenero, J.R., \& Prado, J.G. (1993). Coal basins in the Cantabrian Mountains. International Journal of Coal Geology, 23, 215-229.

Colmenero, J.R., Suárez-Ruiz, I., Fernández-Suárez, J., Barba, P., \& Llorens, T. (2008). Genesis and rank distribution of Upper Carboniferous coal basins in the Cantabrian Mountains, Northern Spain. International Journal of Coal Geology, 76, 187-204.

Dembicki, H. (2016). Practical Petroleum Geochemistry for Exploration and Production. Elsevier, $342 \mathrm{p}$.

Dembicki, H. (2009). Three common source rock evaluation errors made by geologists during prospect or play appraisals. American Association of Petroleum Geologists Bulletin, 93, 341-356.

Emmings, J.F., Davies, S.J., Vane, C.H., Leng, M.J., Moss-Hayes, V., Stephenson, M.H., \& Jenkin, G.R.T., (2018). Stream and slope weathering effects on organic-rich mudstone geochemistry and implications for hydrocarbon source rock assessment: A Bowland Shale case study. Chemical Geology, 471, 74-91.

Espitalié, J., Madec, M., \& Tissot, B. (1980). Role of mineral matrix in kerogen pyrolysis: influence on petroleum generation and migration. American Association of Petroleum Geologists Bulletin, 64, 59-66.

Fernández, J.J. (2006). Posibilidades de aprovechamiento de CBM en la cuenca carbonífera central de Asturias: aplicación a la unidad de La Justa-Aramil (Doctoral dissertation). Unpublished.

Fernández, L.P. (1993). La formación San Emiliano (Carbonífero de la Zona Cantábrica, NO de España): estratigrafía y extensión lateral. Algunas implicaciones paleogeográficas. Trabajos de Geología, 19, 97-122.

Ferrand, A., Grappin, C., García-Iglesias, J., \& Touray, J.C. (1978). Nouvelles données sur le gite de fluorine de Villabona (Asturies-Espagne) et ses conditions de genése. Bulletin du BRGM, Section II 4, 357-369.

Flórez, S. (1998). Tipología de las mineralizaciones de Cu-Co-Ni de Carreña de Cabrales (Asturias) (Master's degree dissertation). Unpublished.

Gao, X., Liu, L., Jiang, F., Wang, Y., Xiao, F., Ren, Z., \& Xiao, Z. (2016). Analysis of geological effects on methane adsorption capacity of continental shale: a case study of the Jurassic shale in the Tarim Basin, northwestern China. Geological Journal, 51, 936-948.

García-Iglesias, J., \& Loredo, J. (1990). Geological, mineralogical and geochemical characteristics of the Carlés gold mineralization, Asturias, Spain. Minerallium Deposita, 25, S53-S58.

García-Iglesias, J., \& Loredo, J. (1992). Yacimientos de fluorita de Asturias. In: Recursos Minerales de España, CSIC (Ed.): 487-497.

García-Iglesias, J., \& Loredo, J. (1994). Geological, geochemical and mineralogical characteristics of the Asturias fluorspar district, northern Spain. Exploration and mining geology, 3, 31-37.

García-Iglesias, J., \& Touray, J.C. (1976). Hydrocarbures liquids en inclusion dans la fluorite du gisement de "La Cabaña" (Berbes, Asturies, Espagne). Bulletin Societe Francaise Mineralogie et Cristallographie, 99, 117-118.

García-Iglesias, J., \& Touray, J.C. (1977). A fluorite-calcite-quartz paragenesis with liquid and gaseous organic inclusions at La Cabaña, Berbes, Asturias fluorspar district, Spain. Economic Geology, 72, 298-303.

García-Iglesias, J. (1978). Estudio de inclusiones fluidas en los depósitos de fluorita de Berbes, Asturias, España. Boletín Instituto Geológico Minero de España, 89, 69-83. 
García-López, S., Bastida, F., Brime, C., Aller, J., Valín, M.L., Sanz-López, J., Méndez, C.A., \& Menéndez-Álvarez, J.R. (1999). Los episodios metamórficos de la Zona Cantábrica y su contexto estructural. Trabajos de Geología, 21, 177-187.

García-López, S., Blanco-Ferrera, S., \& Sanz-López, J. (2006). Aplicación de los conodontos al conocimiento de la evolución tectonotérmica de las zonas externas de los orógenos. Revista española de micropaleontología, 38, 289-297.

García-López, S., Brime, C., Valín, M.L., Sanz-López, J., Bastida, F., Aller, J., \& Blanco-Ferrera, S. (2007). Tectonothermal evolution of a foreland fold and thrust belt: the Cantabrian Zone (Iberian Variscan belt, NW Spain). Terra Nova, 19, 469-475.

García-Loygorri, A., Ortuño, G., Caride, C., Gervilla, M., Greber, C., \& Feys, R. (1971). El Carbonífero de la cuenca central asturiana. Trabajos de Geología, 3, 101-150.

García-Ramos, J.C., Piñuela, L., \& Aramburu, C. (2010). La Fm Tereñes en su localidad tipo. In: Las sucesiones litorales y marinas restringidas del Jurásico Superior. Acantilados de Tereñes (Ribadesella) y de la playa de La Griega (Colunga), University of Oviedo, (Ed.). 5th Congress of the Jurassic of Spain, Guidebook: 15-39.

Gessal (2013). Evaluación preliminar de los recursos prospectivos de hidrocarburos convencionales y no convencionales en España [technical report]. Retrieved from http://aciep.com/sites/default/files/informe_de_sintesis_version_resumida-1_1_0.pdf, accessed $18 / 7 / 2017$.

Gutiérrez-Claverol, M., \& Gallastegui, J. (2002). Prospección de hidrocarburos en la plataforma continental asturiana. Trabajos de Geología, 23, 21-34.

Gutiérrez-Claverol, M., \& García-Iglesias, J. (1982). El yacimiento de magnesita de Valderrodero (Asturias, España). Boletín geológico y minero, 43, 233-243.

Gutiérrez-Claverol, M., Luque, C., García, J.R., \& Rodríguez-Terente, L.M. (2009). La fluorita: un siglo de minería en Asturias. Luque, C. (Ed), 565 p. Oviedo.

Gutiérrez-Claverol, M., \& Torres, M. (1995). Geología de Oviedo. Descripción, recursos y aplicaciones: Paraíso, 275 p. Oviedo.

Gutiérrez-Marco, J.C., Aramburu, C., Arbizu, M., Bernárdez, E., Hacar, M.P., Méndez-Bedia, I., Montesinos López, R., Rábano, I., Truyols, J., \& Villa, E. (1999). Revisión bioestratigráfica de las pizarras del Ordovícico Medio en el noroeste de España (zonas Cantábrica, Asturoccidentalleonesa y Centroibérica septentrional). Acta Geológica Hispanica, 34, 3-87.

Gutiérrez-Marco, J.C., \& Bernárdez, E. (2003). Un tesoro geológico en la Autovía del Cantábrico. El Túnel Ordovícico del Fabar, Ribadesella (Asturias). Ministerio de Fomento (Ed.), 398 p. Madrid.

Hemleben, Ch., \& Reuther, C.D. (1980). Allodapous limestones of the Barcaliente Fm (Namurian A) between Luna and Cea Rivers (Southern Cantabrian Mountains, Spain). Neues Jahrbuch für Geologie und Palaöntologie, 159, 225-255.

Holdtich, S.A. (2011). Unconventional Oil and Gas: Go For the Source [technical report]. Retrieved from http://spesas.org/sites/default/files/slides/unconventional-oil-and-gas.pdf, accessed 21/06/2015.

Jacob, H. (1989). Classification, structure, genesis, and practical importance of natural solid bitumen ("migrabitumen"). International Journal of Coal Geology, 11, 65-79.

Jarvie, D.M. (1991). Total Organic Carbon (TOC) analysis. In: Treatise of Petroleum Geology, Handbook of Petroleum Geology, Source and Migration Processes and Evaluation Techniques, Merrill, R.K. (Ed.). AAPG Press: 113-118. 
Jarvie, D.M. (2012). Shale resource systems for oil and gas: part 1-shale-gas resource systems. In: Shale Reservoirs-Giant Resources for the 21st Century, Breyer, J.A. (Ed.). AAPG Memoir No 97: 69-87.

Jarvie, D.M., Hill, R.J., Ruble, T.E., \& Pollastro, R.M. (2007). Unconventional shale-gas systems: The Mississippian Barnett Shale of north-central Texas as one model for thermogenic shale-gas assessment. American Association of Petroleum Geologists Bulletin, 91, 475-499.

Jiang, Y., Chen, L., Qi, L., Luo, M., Chen, X., Tao, Y., \& Wang, Z. (2017). Characterization of the Lower Silurian Longmaxi marine shale in Changning area in the south Sichuan Basin, China. Geological Journal, DOI: 10.1002/gj.2983.

Jiménez, A. (1995). Estudio del grupo vitrinita en carbones de distinto rango. Determinación de sus propiedades y relaciones con su genesis (Doctoral dissertation). Unpublished.

Katz, B.J. (1983). Limitations of "Rock-Eval" pyrolysis for typing organic matter. Organic Geochemistry, 3-4, 195-199.

Lafarge, E., Espitalié, J., Marquis, F., \& Pillot, D. (1998). Rock-Eval 6 applications in hydrocarbon exploration, production and in soil contamination studies. Oil and Gas Science and technology, 53, 421-437.

Loredo, J. (1981). Aplicación de los estudios de inclusiones fluidas a los yacimientos asturianos de fluorita. (Doctoral dissertation). Unpublished.

Loredo, J., \& García-Iglesias, J. (1993). Mineralogy and fluid inclusions studies of gold-bearing quartz veins in western Asturias, Spain. Exploration and mining geology, 2, 265-270.

Loredo, J., Guilhaumou, N., Touray, J.C., \& García-Iglesias, J. (1984). Estudio de inclusiones fluidas en el yacimiento de fluorita de Oseja (León), en particular inclusiones del sistema $\mathrm{H}_{2} \mathrm{O}$ $\mathrm{SH}_{2}-\mathrm{CO}_{2}-\mathrm{S}$. Datos microtermométricos y microsonda Raman. Boletín geológico y minero, 45, $142-$ 150.

Loredo, J., Luque, C., \& García-Iglesias, J. (1988). Conditions of formation of mercury deposits from the Cantabrian Zone (Spain). Bulletin de Minéralogie, 111, 393-400.

Lotze, F. (1945). Zur gliederung der Variszichen der lberischen Meseta. Geotektonische Forschungen, 6, 78-92.

Maio, F., Aramburu, C., \& Underwood, J. (2011). Geochemistry of Ordovician and Silurian black shales, Cantabrian Zone, Asturias and Leon provinces, Northwest Spain [Search and Discovery article]. Retrieved from

http://www.searchanddiscovery.com/documents/2011/50529maio/ndx_maio.pdf, accesed 10/2/2017.

McGlade, C., Spiers, J., \& Sorrel, S. (2013). Unconventional gas - A review of regional and global resource estimates. Energy, 55, 571-584.

Menor-Salván, C., Tornos, F., Ruiz-Bermejo, M., Fernández-Remolar, D., \& Amils, R. (2008). Biomarkers preserved in fluid inclusions in quartz from the Berbes fluorite deposit (N Spain). Geochimica et Cosmochimica Acta, 72, A620.

Mukhopadhyay, P.K. (1992). Maturation of organic matter as revealed by microscopic methods: applications and limitations of vitrinite reflectance and continuous spectral and pulsed laser fluorescence spectroscopy. In: Diagenesis III, Wolf, K.H., Chilingarian, G.V. (Eds.). Developments in Sedimentology No 47: 435-505.

Paniagua, A., Loredo, J., \& García-Iglesias, J. (1988). Epithermal (Cu-Co-Ni) mineralization in the Aramo mine (Cantabrian Mountains, Spain): correlation between paragenetic and fluid inclusion data. Bulletin de Minéralogie, 111, 383-391. 
Peters, K.E. (1986). Guidelines for evaluating petroleum source rock using programmed pyrolysis. American Association of Petroleum Geologists Bulletin, 70, 318-329.

Peters, K.E., Walters, C.C., Moldowan, J.M. 2005. The biomarker guide (Volume I): biomarkers in the environment and human history. Cambridge University Press (2nd ed.), pp.471. Cambrigde.

Piedad-Sánchez, N., Izart, A., Martínez, L., Suárez-Ruiz, I., Elie, M., \& Menetrier, C. (2004a). Paleothermicity in the Central Asturian Coal Basin, north Spain. International Journal of Coal Geology, 58, 205-229.

Piedad-Sánchez, N., Suárez-Ruiz, I., Martínez, L., Izart, A., Elie, M., \& Keravis, D. (2004b). Organic petrology and geochemistry of the carboniferous coal seams from the Central Asturian Coal Basin (NW Spain). International Journal of Coal Geology, 57, 211-242.

Ramos Rosique, A. (2007). Microscopía, microespectrometría y modelado termodinámico de inclusiones fluidas acuosas y de hidrocarburos. (Doctoral dissertation). Retrieved from http://www.geociencias.unam.mx/ bole/eboletin/tesisAldoRR07.pdf

Raven, J.G.M., \& Van der Pluijm, B.A. (1986). Metamorphic fluids and transtension in the Cantabrian Mountains of northern Spain: an application of the conodont colour alteration index. Geological Magazine, 123, 673-681.

Rejebian, V.A., Harris, A.O., \& Huebner, J.S. (1987). Conodont colour and textural alteration: An index to regional metamorphism, contact metamorphism, and hydrothermal alteration. Geological Society of America Bulletin, 99, 471-479.

Ross, D., \& Bustin, R.M. (2008). Characterizing the shale gas resource potential of DevonianMississippian strata in the western Canada sedimentary basin: Application of an integrated formation evaluation. American Association of Petroleum Geologists Bulletin, 92, 87-12.

Rua-Figueroa, A., Llavona, M., Loredo, J., \& García-Iglesias, J. 1987. Fluid inclusions in quartz from a gold-mineralized granodioritic intrusion at Carlés, Asturias, Spain. Chemical Geology, 61, 217-224.

Sánchez, V., Vindel, E., Martín-Crespo, T., Corbella, M., Cardellach, E., \& Banks, D.A. (2009). Sources and composition of fluids associated with fluorite deposits of Asturias (N Spain). Geofluids, 9, 338-355.

Sastre, J. (2013). Posibilidades de almacenamiento geológico de $\mathrm{CO}_{2}$ en capas de carbón con recuperación mejorada de metano (Doctoral dissertation). Unpublished.

Suárez-Ruiz, I. (1988). Caracterización, clasificación y estudio de la evolución de la materia orgánica dispersa (MOD) en el Jurásico de Asturias y Cantabria. (Doctoral dissertation). Unpublished.

Suárez-Ruiz, I., \& González-Prado, J.G. (1986). Estudio microscópico de la materia orgánica en las pizarras bituminosas del Lías en el litoral de Cantabria. Acta Geológica Hispánica, 21-22, 585591.

Suárez-Ruiz, I., \& González-Prado, J.G. (1990). Estudio y clasificación de la materia orgánica dispersa (MOD) en el Lías de la playa de Peñarrubia (Asturias). Estudios geológicos, 46, 81-92.

Suárez-Ruiz, I., \& González-Prado, J. 1995. Characterization of Jurassic Black Shales from Asturias (Northern Spain): Evolution and Petroleum Potential. In: Composition, Geochemistry and Conversion of Oil Shales, Snape, C.E. (Ed.): 387-393.

Suárez-Ruiz, I., \& González-Prado, J G. (1996). Estudio sobre la evolución de ictiorrestos en pizarras bituminosas. Geogaceta, 20, 657-659.

Suárez-Ruiz, I., Iglesias, M., Jiménez, A., Laggoun-Defarge, F., \& Prado, J.G. 1994. Petrographic and geochemical anomalies detected in the Spanish Jurassic jet. In: Vitrinite reflectance as a maturity parameter: applications and limitations, Mukhopadhyay, P.K., Dow, W.G. (Eds.): 76-92. 
US EIA (2015). Annual Energy Outlook 2015 with projections to 2040 [technical report].

Retrieved from https://www.eia.gov/outlooks/aeo/pdf/0383(2015).pdf, accessed 27/03/2017. 
Table 1. Compilation of published data about the thermal maturation in the sub-units of the CZ. VR: vitrinite reflectance; CAI: Conodont Alteration Index; KI: Kübler Index (illite crystallinity); $\mathrm{T}_{\max }$ : Temperature of maximum hydrocarbon generation during the Rock-Eval pyrolysis.

\begin{tabular}{|c|c|c|c|c|c|c|}
\hline Unit & $\operatorname{VR}\left(\% \mathbf{R}_{\mathbf{0}}\right)$ & CAI & $\mathbf{K I}$ & $\mathbf{T}_{\max }$ & Biomarkers & $\begin{array}{l}\text { Fluid Inclusions } \\
\end{array}$ \\
\hline $\begin{array}{l}\text { Somiedo, La } \\
\text { Sobia and } \\
\text { Aramo }\end{array}$ & $\begin{array}{l}\text { Maio et al. (2011) } \\
\text { Colmenero et al. (2008) }\end{array}$ & $\begin{array}{l}\text { García-López et al. (2006, } \\
\text { 2007); Bastida et al. (2002); } \\
\text { Aller et al. (2005); Brime et } \\
\text { al. (2001); Raven and Van } \\
\text { der Pluigm (1986); García- } \\
\text { López et al. (1999) }\end{array}$ & $\begin{array}{l}\text { Aller et al. (2005); Bastida } \\
\text { et al. (2002); Brime et al. } \\
\text { (2001); Aparicio et al. } \\
\text { (1993); Brime and Pérez- } \\
\text { Estaún (1980); García- } \\
\text { López et al. (1999) }\end{array}$ & $\begin{array}{l}\text { Maio et al. } \\
(2011)\end{array}$ & NA & $\begin{array}{l}\text { Ferrand et al. (1978); Loredo (1981); } \\
\text { García-Iglesias and Loredo (1990, } \\
\text { 1992, 1994); Cepedal (2001); } \\
\text { Sánchez et al. (2009); Gutiérrez- } \\
\text { Claverol et al. (2009); Loredo et al. } \\
\text { (1988); Gutiérrez-Claverol and } \\
\text { García-Iglesias (1982); Loredo and } \\
\text { García-Iglesias (1993); Rua-Figueroa } \\
\text { et al. (1987) }\end{array}$ \\
\hline $\begin{array}{c}\text { Central } \\
\text { Coal Basin }\end{array}$ & $\begin{array}{l}\text { Maio et al. (2011); } \\
\text { Colmenero et al. (2008); } \\
\text { Piedad-Sánchez et al. } \\
\text { (2004a,b); Colmenero and } \\
\text { Prado (1993); Águeda et } \\
\text { al. (1991) }\end{array}$ & $\begin{array}{l}\text { García-López et al. (2007); } \\
\text { García-López et al. (1999) }\end{array}$ & $\begin{array}{l}\text { Aparicio et al. (1993); } \\
\text { Alonso and Brime (1990); } \\
\text { García-López et al. (1999) }\end{array}$ & $\begin{array}{l}\text { Maio et al. } \\
(2011) \\
\text { Piedad- } \\
\text { Sánchez et al. } \\
(2004 a, b)\end{array}$ & $\begin{array}{l}\text { Piedad- } \\
\text { Sánchez et al. } \\
\text { (2004a,b) } \\
\text { Menor-Salván } \\
\text { et al. (2008) }\end{array}$ & $\begin{array}{l}\text { García-Iglesias and Touray (1976, } \\
\text { 1977); García-Iglesias (1978); } \\
\text { Loredo (1981); Loredo et al. (1988); } \\
\text { Paniagua et al. (1988); Arcos and } \\
\text { Tornos (1997); Sánchez et al. (2009); } \\
\text { Ramos Rosique (2007); Gutiérrez- } \\
\text { Claverol et al. (2009); García-Iglesias } \\
\text { and Loredo (1992,1994) }\end{array}$ \\
\hline $\begin{array}{l}\text { Ponga } \\
\text { Nappe }\end{array}$ & Colmenero et al. (2008) & $\begin{array}{l}\text { Blanco-Ferrera et al. (2011, } \\
\text { 2016) } \\
\text { García-López et al. (2007) } \\
\text { García-López et al. (1999) }\end{array}$ & $\begin{array}{l}\text { Blanco-Ferrera et al. (2011, } \\
\text { 2016); Aparicio et al. (1993) }\end{array}$ & NA & NA & $\begin{array}{l}\text { Loredo (1981); García-Iglesias and } \\
\text { Loredo (1992); Gutiérrez-Claverol et } \\
\text { al. (2009); Alonso (1974); Loredo et } \\
\text { al. (1988) }\end{array}$ \\
\hline $\begin{array}{l}\text { Picos de } \\
\text { Europa }\end{array}$ & NA & $\begin{array}{l}\text { García-López et al. (2006, } \\
\text { 2007); Bastida et al. (2004); } \\
\text { García-López et al. (1999) }\end{array}$ & $\begin{array}{l}\text { Blanco et al, 2016; Aparicio } \\
\text { et al. (1993) }\end{array}$ & NA & NA & $\begin{array}{l}\text { Flórez (1998); Loredo et al. (1984, } \\
\text { 1988) }\end{array}$ \\
\hline $\begin{array}{l}\text { Meso- } \\
\text { Tertiary } \\
\text { cover }\end{array}$ & $\begin{array}{l}\text { Jiménez (1995); Suárez- } \\
\text { Ruiz et al. (1994); Suárez- } \\
\text { Ruiz and González-Prado } \\
(1986,1990,1996) ; \\
\text { Suárez-Ruiz (1988) }\end{array}$ & NA & NA & NA & $\begin{array}{l}\text { Blanco et al. } \\
(1996)\end{array}$ & $\begin{array}{l}\text { Loredo (1981); García-Iglesias and } \\
\text { Loredo (1992); Sánchez et al. (2009); } \\
\text { Gutiérrez-Claverol et al. (2009) }\end{array}$ \\
\hline
\end{tabular}


Table 2. Characteristics of the lithostratigraphic units sampled in this study.

\begin{tabular}{|c|c|c|c|c|c|c|c|c|c|}
\hline \multirow[b]{2}{*}{ Formation } & \multirow[b]{2}{*}{ Age } & \multirow{2}{*}{$\begin{array}{c}\text { Petrographical } \\
\text { type }\end{array}$} & \multirow{2}{*}{$\begin{array}{l}\text { Thickness } \\
\text { (m) }\end{array}$} & \multicolumn{4}{|c|}{ Sampling section } & \multirow{2}{*}{$\begin{array}{c}\text { No. } \\
\text { samples }\end{array}$} & \multirow{2}{*}{$\begin{array}{l}\text { CZ sub- } \\
\text { unit }\end{array}$} \\
\hline & & & & Place & Xutm & YUTM & $\begin{array}{l}\text { UTM zone } \\
\text { (ETRS89) }\end{array}$ & & \\
\hline \multirow{2}{*}{ Luarca } & \multirow{2}{*}{$\begin{array}{c}\text { Ordovician } \\
\text { (Dobrotivian) }\end{array}$} & \multirow{2}{*}{ Slates and lutites } & \multirow{2}{*}{$\begin{array}{c}370-450 \\
\text { (1) }\end{array}$} & Peñas Cappe & 269597 & 4836247 & 30 & \multirow{2}{*}{14} & \multirow{9}{*}{$\begin{array}{l}\text { Somiedo } \\
\text {-La } \\
\text { Sobia }\end{array}$} \\
\hline & & & & Vidrias Cappe & 740764 & 4829829 & 29 & & \\
\hline \multirow{2}{*}{ Formigoso } & Silurian & Siltstones and & $70-200$ & Llumeres & 271582 & 4836038 & 30 & \multirow{2}{*}{19} & \\
\hline & (Llandovery) & lutites & (2) & Clavillas & 722803 & 4782525 & 29 & & \\
\hline \multirow{3}{*}{ Rañeces } & \multirow{3}{*}{$\begin{array}{c}\text { Devonian } \\
\text { (Lochkovian- } \\
\text { Emsian) }\end{array}$} & \multirow{3}{*}{$\begin{array}{c}\text { Limestones, } \\
\text { graywackes and } \\
\text { lutites }\end{array}$} & \multirow{3}{*}{$\begin{array}{c}550-680 \\
(3)\end{array}$} & Fabar & 737319 & 4786643 & 29 & \multirow{3}{*}{14} & \\
\hline & & & & Las Vegas & 740427 & 4795797 & 29 & & \\
\hline & & & & Xagó beach & 264876 & 4832622 & 30 & & \\
\hline $\begin{array}{c}\text { Naranco } \\
\text { Group }\end{array}$ & $\begin{array}{l}\text { Carboniferous } \\
\text { (Westphalian) }\end{array}$ & $\begin{array}{c}\text { Graywackes and } \\
\text { litharenites }\end{array}$ & $\begin{array}{c}1200 \\
(4)\end{array}$ & Los Carriles & 267506 & 4810148 & 30 & 10 & \\
\hline $\begin{array}{c}\text { San } \\
\text { Emiliano }\end{array}$ & $\begin{array}{l}\text { Carboniferous } \\
\text { (Westphalian) }\end{array}$ & Lutites & $\begin{array}{c}2000 \\
(5)\end{array}$ & Casares & 274641 & 4757787 & 30 & 11 & \\
\hline \multirow{2}{*}{ Sueve } & \multirow{2}{*}{$\begin{array}{l}\text { Ordovician } \\
\text { (Dobrotivian) }\end{array}$} & \multirow{2}{*}{ Lutites } & 90 & Pico Pienzu & 320019 & 4810581 & 30 & \multirow{2}{*}{9} & \multirow{4}{*}{$\begin{array}{c}\text { Central } \\
\text { Coal } \\
\text { basin }\end{array}$} \\
\hline & & & $(6)$ & Peñamayor & 296692 & 4798922 & 30 & & \\
\hline \multirow[b]{2}{*}{ Fresnedo } & \multirow{2}{*}{$\begin{array}{l}\text { Carboniferous } \\
\text { (Namurian- } \\
\text { Westphalian) }\end{array}$} & \multirow{2}{*}{$\begin{array}{c}\text { Graywackes and } \\
\text { lutites }\end{array}$} & \multirow{2}{*}{$\begin{array}{l}470 \\
(7)\end{array}$} & Rioseco & 300299 & 4788733 & 30 & \multirow[b]{2}{*}{17} & \\
\hline & & & & Felechosa & 298745 & 4775585 & 30 & & \\
\hline Barcaliente & $\begin{array}{l}\text { Carboniferous } \\
\text { (Namurian) }\end{array}$ & $\begin{array}{l}\text { Limestones } \\
\text { (mudstone) }\end{array}$ & $\begin{array}{c}250 \\
(8)\end{array}$ & Samalea & 317518 & 4801753 & 30 & 5 & \multirow{3}{*}{$\begin{array}{c}\text { Ponga } \\
\text { Unit }\end{array}$} \\
\hline Beleño & $\begin{array}{l}\text { Carboniferous } \\
\text { (Westphalian) }\end{array}$ & $\begin{array}{l}\text { Lutites and } \\
\text { litharenites }\end{array}$ & $\begin{array}{l}185-900 \\
\text { (9) }\end{array}$ & Sardeu & 328134 & 4812106 & 30 & 9 & \\
\hline Fito & $\begin{array}{l}\text { Carboniferous } \\
\text { (Westphalian) }\end{array}$ & $\begin{array}{c}\text { Litharenites and } \\
\text { graywackes }\end{array}$ & $\begin{array}{l}\text { up to } 1400 \\
\text { (9) }\end{array}$ & Coballes & 306644 & 4784736 & 30 & 10 & \\
\hline Rodiles & $\begin{array}{c}\text { Jurassic } \\
\text { (Sinemurian- } \\
\text { Toarcian) } \\
\end{array}$ & $\begin{array}{l}\text { Limestones (mud- } \\
\text { and wackestone) }\end{array}$ & $\begin{array}{c}50-80 \\
(10)\end{array}$ & Vega beach & 327666 & 4816626 & 30 & 7 & \multirow{2}{*}{$\begin{array}{l}\text { Meso- } \\
\text { Tertiary } \\
\text { cover }\end{array}$} \\
\hline Tereñes & $\begin{array}{c}\text { Jurassic } \\
\text { (Kimmeridgian) }\end{array}$ & $\begin{array}{l}\text { Limestones (mud- } \\
\text { and wackestones) }\end{array}$ & $\begin{array}{l}160 \\
(11)\end{array}$ & Tereñes cliff & 330213 & 4815677 & 30 & 9 & \\
\hline
\end{tabular}

(1) Gutiérrez-Marco et al., 1999; (2) Aramburu et al., 1992; (3) Bulnes, García-Alcalde \& Marcos, 1999; (4) Gutiérrez-Claverol \& Torres, 1995; (5)

Fernández, 1993; (6) Aramburu\& García-Ramos, 1993; (7) García-Loygorri et al., 1971; (8) Bahamonde, Merino-Tomé, Della Porta \& Villa, 2015;

(9) Bahamonde \& Colmenero, 1993; (10) Bádenas, Aurell, García-Ramos, González \& Piñuela, 2009; (11) García-Ramos, Piñuela \& Aramburu,

2010 
Table 3. Total organic carbon content, Rock-Eval S1, S2 (both mg hydrocarbon/g rock) and $\mathrm{S} 3$ (mg CO $2 / \mathrm{g}$ rock) peaks, Hydrogen and Oxygen Indexes (mg hydrocarbon/g TOC and $\mathrm{mg} \mathrm{CO} / \mathrm{g}$ TOC, respectively), Maturation (\% $\mathrm{R}_{0}$ and TAI) and visual analysis of kerogen for the samples collected in this work.

\begin{tabular}{|c|c|c|c|c|c|c|c|c|c|c|c|}
\hline \multirow[b]{2}{*}{ Formation } & \multicolumn{3}{|c|}{ TOC (\%) } & \multicolumn{5}{|c|}{ Rock-Eval test } & \multicolumn{2}{|c|}{ Maturation } & \multirow[b]{2}{*}{ Kerogen visual analysis } \\
\hline & Min & Max & Mean & S1 & $\mathbf{S 2}$ & $\mathbf{S 3}$ & HI & OI & $\begin{array}{l}\mathbf{R}_{0} \\
(\%)\end{array}$ & TAI & \\
\hline Luarca & 0.065 & 0.59 & 0.38 & 0.04 & 0.07 & 0.53 & 9 & 123 & 1.70 & 4 & - \\
\hline Formigoso & 0.15 & 1.23 & 0.57 & 0.03 & 0.06 & 1.35 & 5 & 110 & 1.09 & 3 & $\begin{array}{l}\text { Amorphous organic matter and } \\
\text { solid bitumen }\end{array}$ \\
\hline Rañeces & 0.11 & 0.91 & 0.40 & 0.02 & 0.1 & 0.72 & 48 & 343 & 1.01 & - & - \\
\hline Naranco & 0.13 & 6.88 & 0.93 & 0.04 & 1.51 & 1.53 & 165 & 430 & 0.78 & - & - \\
\hline $\begin{array}{l}\text { San } \\
\text { Emiliano }\end{array}$ & 0.19 & 5.71 & 1.01 & 0.02 & 0.54 & 0.98 & 9 & 17 & 0.66 & 2.5 & $\begin{array}{l}\text { Vitrinite and amorphous } \\
\text { organic matter }\end{array}$ \\
\hline Sueve & 0.1 & 0.75 & 0.31 & 0.04 & 0.05 & 0.54 & 7 & 72 & 1.69 & 4 & $\begin{array}{l}65 \% \text { liptinite, } 20 \% \text { pseudo- } \\
\text { vitrinite, } 15 \% \text { inertinite }\end{array}$ \\
\hline Fresnedo & 0.07 & 2.08 & 0.67 & 0.01 & 0.07 & 0.78 & 3 & 36 & 1.07 & 3 & $\begin{array}{l}\text { Vitrinite and some amorphous } \\
\text { organic matter }\end{array}$ \\
\hline Barcaliente & 0.19 & 1.22 & 0.49 & 0.76 & 1.53 & 0.79 & 403 & 208 & 1.35 & 3.3 & $\begin{array}{l}\text { Amorphous organic matter and } \\
\text { solid bitumen }\end{array}$ \\
\hline Beleño & 0.20 & 0.95 & 0.46 & 0.01 & 0.04 & 0.49 & 5 & 65 & 0.62 & 2.5 & $\begin{array}{l}\text { Amorphous organic matter and } \\
\text { vitrinite }\end{array}$ \\
\hline Fito & 0.56 & 3.11 & 1.07 & 0.02 & 0.07 & 0.61 & 7 & 58 & 0.68 & 2.5 & $\begin{array}{l}\text { Amorphous organic matter and } \\
\text { vitrinite }\end{array}$ \\
\hline Rodiles & 0.77 & 5.24 & 2.67 & 1.36 & 3.78 & 1.53 & 75 & 30 & 1.16 & - & Inertinite and some vitrinite \\
\hline Tereñes & 0.51 & 3.31 & 1.33 & 0.29 & 0.66 & 0.81 & 42 & 68 & 1.09 & - & Inertinite and some vitrinite \\
\hline
\end{tabular}


Table 4. Source rocks classification for hydrocarbon generation potential in relation to lithology and TOC content (based on Holdtich, 2011).

\begin{tabular}{ccc}
$\begin{array}{c}\text { Hydrocarbon generation } \\
\text { potential }\end{array}$ & $\begin{array}{c}\text { TOC }(\% \text { wt) } \\
\text { (lutites and shales) }\end{array}$ & $\begin{array}{c}\text { TOC }(\% \mathbf{w t}) \\
\text { (limestones) }\end{array}$ \\
\hline Poor & $<0.5$ & $<0.2$ \\
\hline Fair & $0.5-1.0$ & $0.2-0.5$ \\
\hline Good & $1.0-2.0$ & $0.5-1.0$ \\
\hline Very good & $2.0-5.0$ & $1.0-2.0$ \\
\hline Excellent & $>5.0$ & $>2.0$ \\
\hline
\end{tabular}


Table 5. Potential for hydrocarbon generation (quantity) as a function of Rock-Eval S1 and S2 peak values; Main products and kerogen type vs HI (Peters et al., 2005).

\begin{tabular}{cccc}
$\begin{array}{c}\text { Hydrocarbon } \\
\text { generation potential }\end{array}$ & $\begin{array}{c}\text { S1 } \\
(\mathbf{m g} / \mathbf{g} \text { rock })\end{array}$ & $\begin{array}{c}\text { S2 } \\
(\mathbf{m g} / \mathbf{g} \text { rock })\end{array}$ & $\begin{array}{c}\text { Hydrocarbon } \\
\text { generation } \\
\text { (mg/kg rock) }\end{array}$ \\
\hline Poor & $<0.5$ & $<2.5$ & $<300$ \\
\hline Fair & $0.5-1$ & $2.5-5$ & $300-600$ \\
\hline Good & $1-2$ & $5-10$ & $600-1200$ \\
\hline Very good & $2-4$ & $10-20$ & $1200-2400$ \\
\hline Excellent & $>4$ & $>20$ & $>2400$ \\
\hline Kerogen type & HI $(\mathbf{m g} / \mathbf{g}$ TOC) & \multicolumn{2}{c}{ Product (main) } \\
\hline I & $>600$ & \multicolumn{2}{c}{ Oil } \\
\hline II & $300-600$ & Oil \\
\hline II/III & $200-300$ & Oil and/or gas \\
\hline III & $50-200$ & \multicolumn{2}{c}{ Gas } \\
\hline IV & $<50$ & \multicolumn{2}{c}{ None }
\end{tabular}


Table 6. Stages of hydrocarbon generation and kerogen type versus vitrinite reflectance $(\%)$.

\begin{tabular}{cccc}
\multicolumn{3}{c}{ Kerogen type } & \multirow{2}{*}{ Zone } \\
\hline I & II & III & Immature \\
\hline 0.7 & 0.55 & 0.65 & Oil \\
\hline $0.7-1.35$ & $0.55-1.25$ & $0.65-1.35$ & Wet gas \\
\hline $1.35-2$ & $1.25-2$ & $1.35-2$ & Dry gas \\
\hline
\end{tabular}




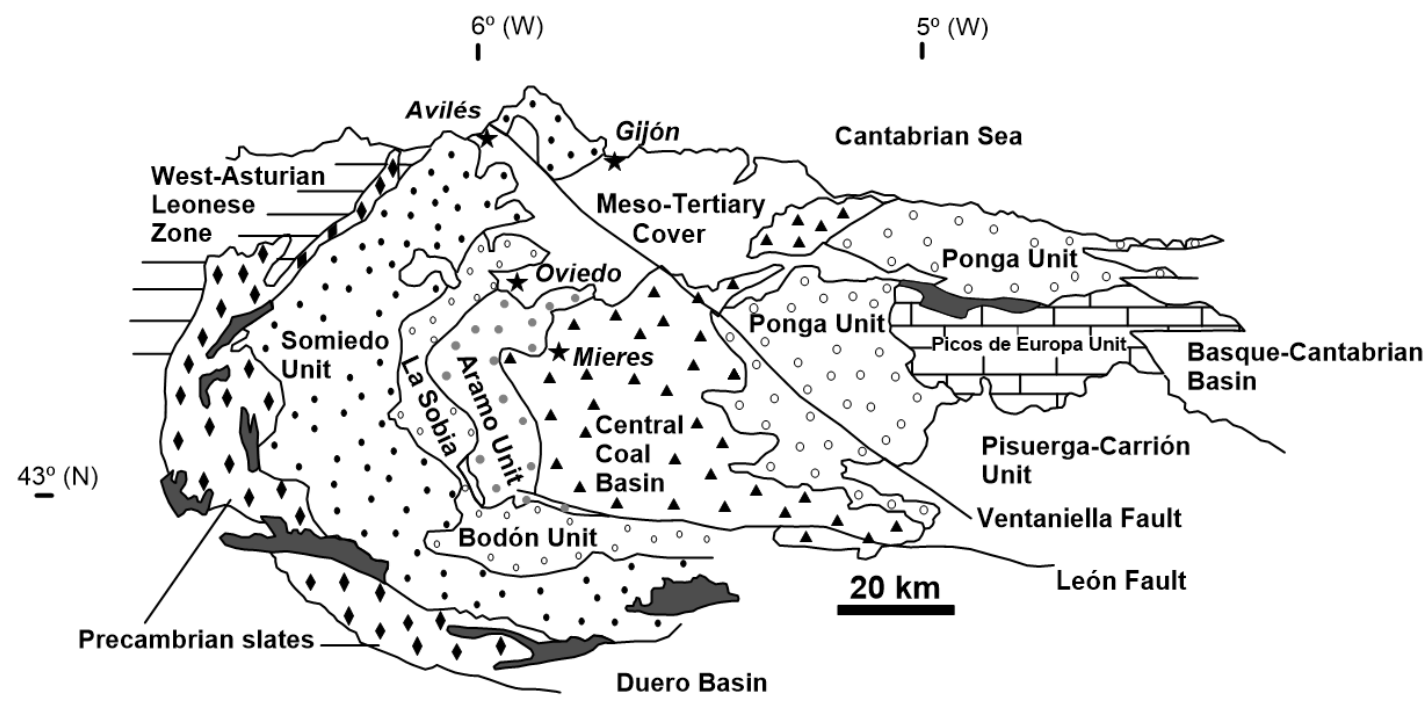

Figure 1. Division of the Cantabrian Zone into structural units. Disperse dark grey outcrops correspond to Stephanian uncomformable rocks. The limit between the WestAsturian Leonese and the Cantabrian Zones is the contact (thrust) that overlaps the Precambrian slates above the Palaeozoic series of the Somiedo unit. 


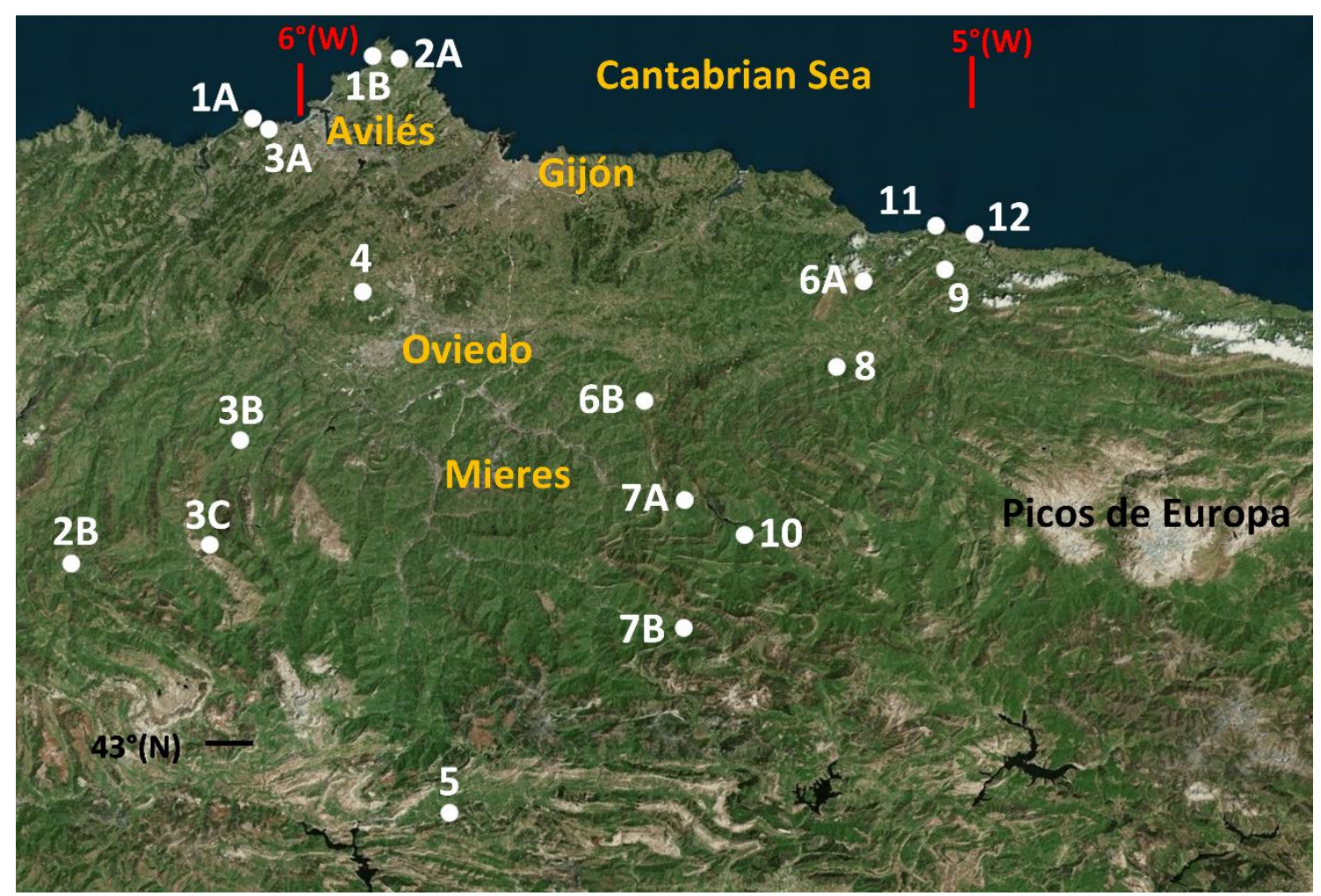

Figure 2. Sampling sections. Luarca Fm [Vidrias Cappe section (1A) and Peñas Cappe section (1B)]; Formigoso Fm [Llumeres section (2A) and Clavillas section (2B)]; Rañeces Group [Santa María del Mar section (3A), Las Vegas Section (3B) and Fabar section (3C)]; Naranco Group [Los Carriles section (4)]; San Emiliano Fm [Casares section (5)]; Sueve Fm [Pico Pienzu section (6A) and Peñamayor section (6B)]; Fresnedo Fm [Rioseco section (7A) and Felechosa section (7B)]; Barcaliente Fm [Samalea section (8)]; Beleño Fm [Sardeu section (9)] Fito Fm [Coballes section (10)]; Rodiles Fm [Vega beach section (11)]; Tereñes Fm [Tereñes section (12)]. Horizontal framing: $140 \mathrm{~km}$. 

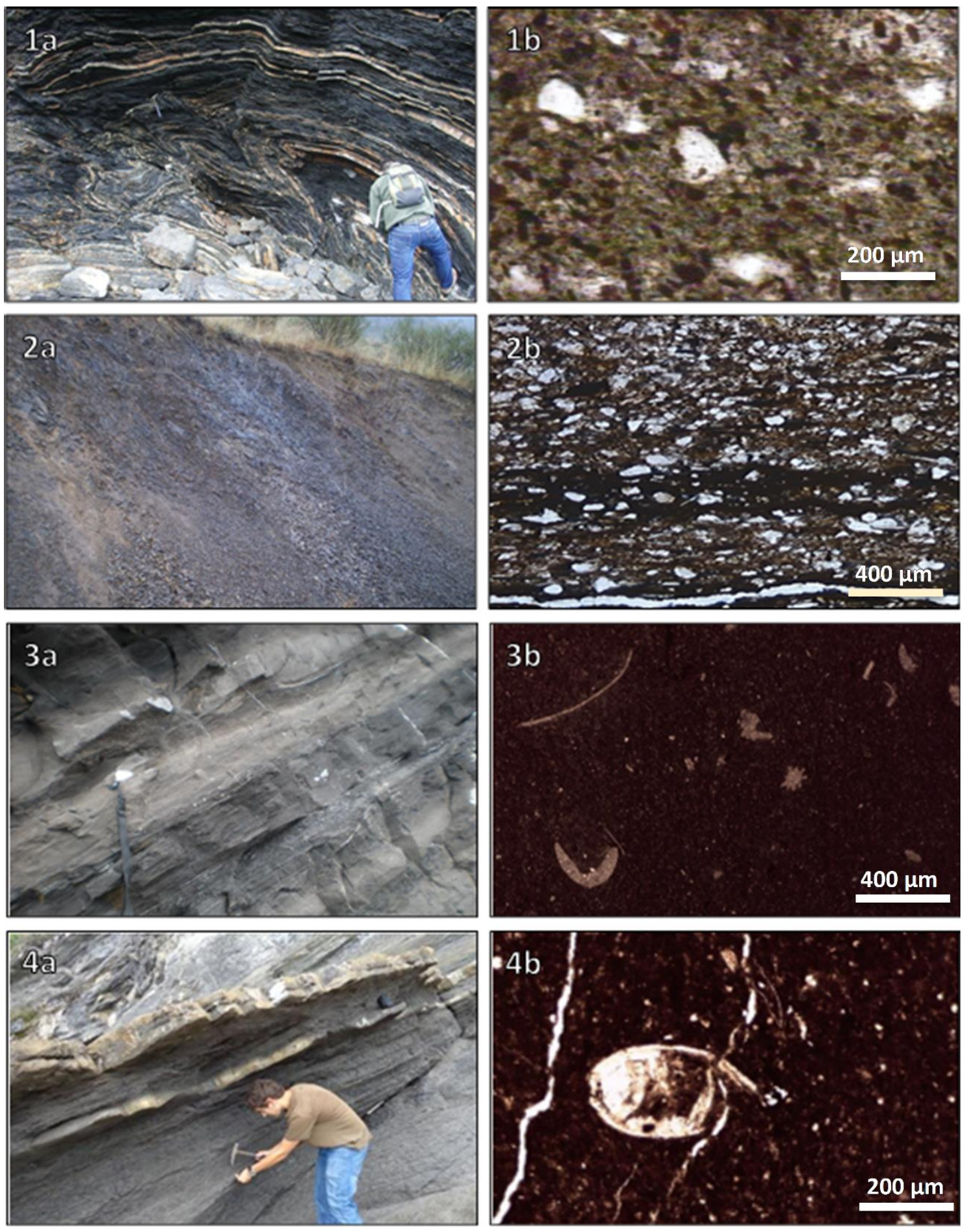

Figure 3. Outcrop and thin section images of selected rocks. 1) Siltstones and lutites of the Formigoso Fm: 1a) outcrop and 1b) thin section image showing the typical silty-clayey texture with quartz and opaque grains 2) Lutites of San Emiliano Fm: 2a) outcrop and 2b) laminated clayey texture with quartz and mica grains 3) Rodiles Fm: 3a) outcrop and 3b) thin section image showing a limestone with biomicritic texture and very fine-grained dispersed quartz; 4) Tereñes Fm: 4a) outcrop and 4b) biomicritic limestone with bivalve fragments and disperse silt-sized quartz as well as open fractures 


\section{HI Vs Ol}

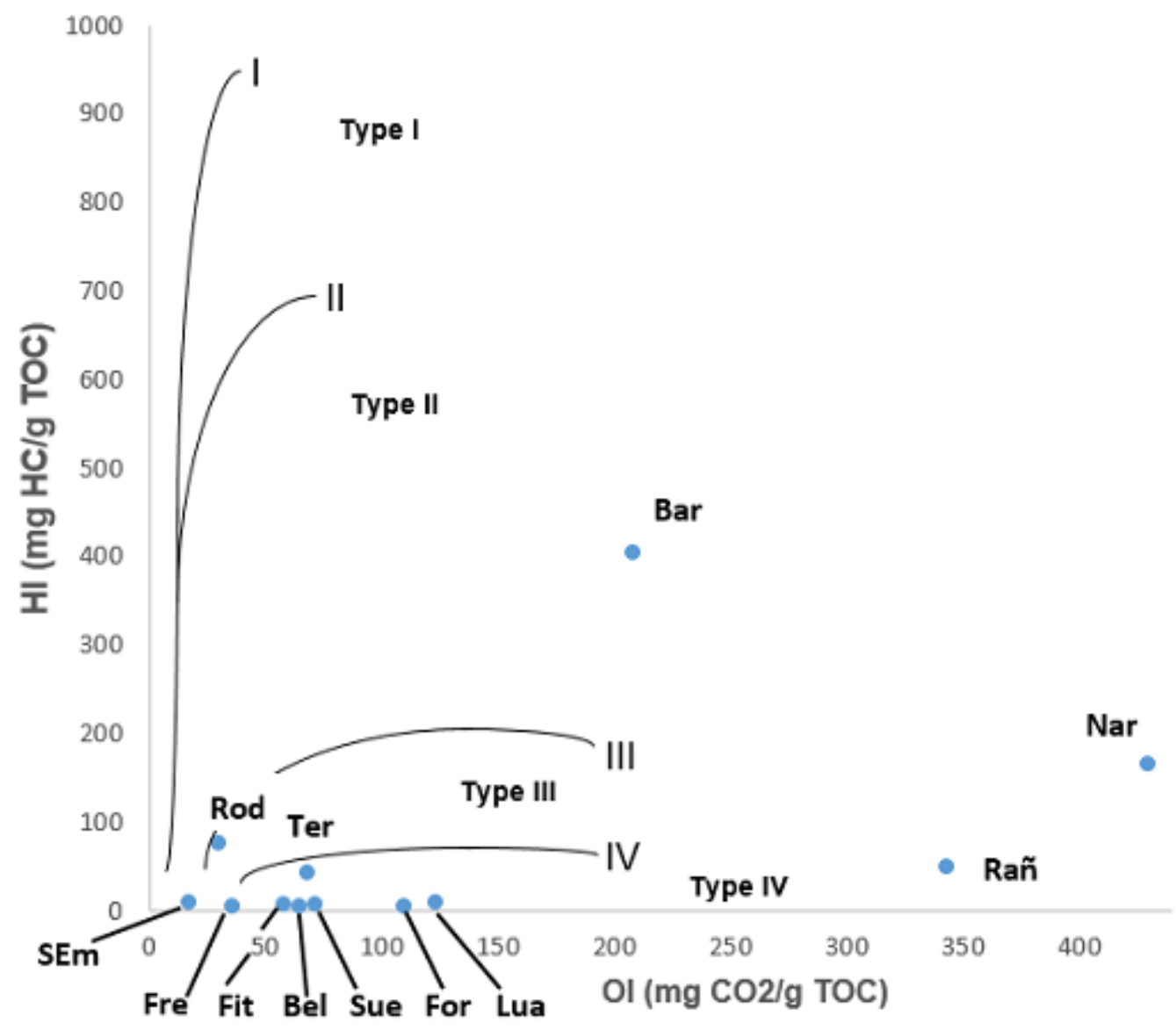

Figure 4. Pseudo Van Krevelen diagram from HI/OI data (SEm: San Emiliano; Fre: Fresnedo; Fit: Fito; Bel: Beleño; Sue: Sueve; For: Formigoso; Lua: Luarca; Rod: Rodiles; Ter: Tereñes; Bar: Barcaliente; Rañ: Rañeces; Nar: Naranco Group (Folgueras and Carriles formations). 


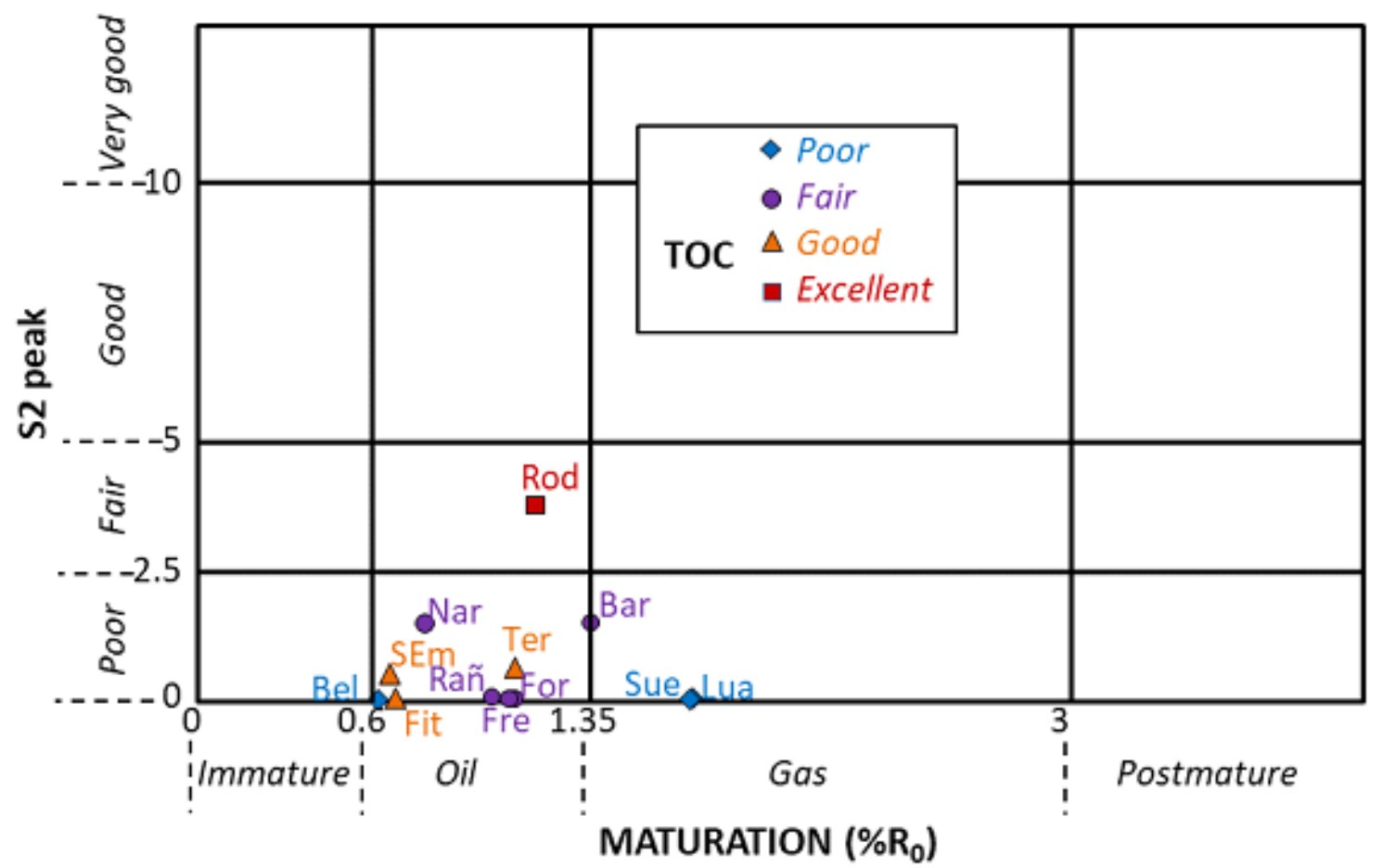

Figure 5. Synthetic diagram including organic matter quantity, quality and maturation of each potential source rock. Average TOC values (\%) are represented according to the rock classification shown in Table 4. References for the formations are those used in Figure 4. 